\section{Effect of Postharvest Soil and Foliar Application of Boron Fertilizer on the Partitioning of Boron in Apple Trees}

\author{
Enrique E. Sánchez ${ }^{1}$ \\ INTA Alto Valle, CC 782, 8332 General Roca, Argentina
}

\author{
Timothy L. Righetti \\ Department of Horticulture, Oregon State University, Corvallis, OR 97331
}

Additional index words. foliar nutrition, fruit trees, isotopes, Malus domestica, 'Delicious'

\begin{abstract}
This study was carried out on mature 'Delicious' apple trees (Malus domestica Borkh.) on EM 9 rootstock. Labeled B $\left(99.63\right.$ Atom $\left.\%{ }^{10} \mathrm{~B}\right)$ was applied as boric acid. Treatments were postharvest foliar B at $375 \mathrm{mg} \cdot \mathrm{L}^{-1}$, postharvest foliar B $\left(375 \mathrm{mg} \cdot \mathrm{L}^{-1}\right)$ plus urea $(2.5 \% \mathrm{wt} / \mathrm{vol})$, and a soil application at the same per-tree rate as the foliar treatments (16 g boric acid/tree). Postharvest foliar B applied with or without urea was efficiently transported from the leaves into storage tissues for the next year's growth. However, soil-applied $B$ remained mostly in the roots while very little was translocated to the above-ground portions of the tree at full bloom. When urea was added to a foliar $B$ spray, the amount of $B$ in the roots and flower clusters increased at full bloom. Although increasing the efficiency of foliar $B$ applications may not be necessary, combining urea and $B$ into a single application is recommended when growers want to apply both $N$ and B. Shoot leaves from all treatments collected late in the season (midsummer) had similar $B$ concentrations, even though treatments altered the amount of added $B$ that was present in different tree tissues early in the season.
\end{abstract}

Boron is an essential micronutrient. When it is not present in sufficient quantity, apple and pear profits are reduced. A major effect of $\mathrm{B}$ nutrition in fruit trees is its role in fruit set (Faust, 1989). Early research indicated that B is necessary for flower bud formation (Kamali and Childers, 1970), production of pollen grains in corn (Zea maize L.) (Argawala et al., 1981), and pollen tube growth in non-fruiting species (Dickinson, 1978; Vasil, 1963). Boron applications increase fruit set in 'Anjou' pear (Pyrus communis L.) (Bajter and Thompson, 1949), 'Stayman' apple (Malus domestica Borkh.) (Bramlage and Thompson, 1962), 'Italian' prune (Prunus domestica L.) (Callan et al., 1978; Chaplin et al., 1977; Hanson and Breen, 1985), and sour cherry (Prunus cerasus L.) (Hanson, 1991a).Aminimum B threshold value of 35 to $40 \mathrm{mg} \cdot \mathrm{kg}^{-1}$ in late summer midshoot leaves has been established for most deciduous fruit tree species (Mills and Jones, 1986). Yield may increase following foliar B application even for trees that exhibit leaf B concentrations within the desirable range (Chaplin et al., 1977). This observation indicates that standard leaf analysis may not be suitable for diagnosing transient B deficiency early in the growing season (Brown, 2001).

Boron is absorbed from the soil solution by roots, mainly as undissociated boric acid, and behaves as a mobile nutrient in the soil. Therefore, small soil B applications easily provide adequate B to trees. However, commercial broadcast guidelines for soil B application must deal with the difficulty of equally distribut-

\footnotetext{
Received for publication 5 May 2005. Accepted for publication 1 Aug. 2005.

${ }^{1}$ To whom reprint requests should be addressed; e-mail esanchez@correo.inta.gov.ar.
}

ing small amounts of fertilizer. Recently, the increasing popularity of mechanical irrigation systems, especially drip irrigation, make fertigation a useful technique for delivering precise amounts of nutrient to individual trees. Routine additions of B in fertigation systems are likely to become increasingly common.

Foliar fertilization with micronutrients is generally successful because deliverable amounts are enough to meet most tree requirements. At present, most growers apply foliar B. Because transitory low B status may limit fruit set, the goal of foliar B programs is to increase B in flower buds. Boron sprays often are applied in early fall after harvest or during the prepink blossom stage (Peryea, 1994). Timing of B maintenance sprays is not critical for apple trees if the trees already contain adequate amounts of $B$ and do not show visual evidence of B insufficiency (Peryea et al., 2003).

Many growers are using postharvest foliar urea applications as a way to ensure that bud reserves of $\mathrm{N}$ are high, even when added fertilizer $\mathrm{N}$ is being reduced with the goal of increasing crop quality (Sánchez et al., 1995). There is also some evidence that a postharvest urea application increases leaf decay rates and reduces the incidence of disease the following year (Beresford et al., 2000; Burchill, 1968). It is important to determine whether B can be added effectively to a postharvest foliar urea application, thus eliminating the need for a B application the following spring.

Using the stable isotope ${ }^{10} \mathrm{~B}$, Sánchez et al. (1998) demonstrated that for pear a single postharvest spray of B dramatically increased the $\mathrm{B}$ concentration in flower buds in the winter and flower clusters at full bloom. Thus, nonlimiting amounts of B were available for fruit set and early fruit and shoot growth. When urea was added to a foliar B spray, B uptake increased (Sánchez et al., 1998).

However, not all species are equally efficient in absorbing nutrients from the leaves (Leece, 1976), and apples are thought to have better foliar uptake capabilities than other fruit species (Picchioni et al., 1995).

The purpose of this research was to determine the uptake and transport effectiveness of postharvest foliar application of B for apple, to compare the effectiveness of foliar B application with and without urea in increasing $\mathrm{B}$ reserves in the tree, and to compare the efficiency of soil- and foliar-applied B.

\section{Materials and Methods}

The study was conducted on mature 'Delicious'/EM 9 apple trees (Malus domestica Borkh.) spaced $2.5 \times 4 \mathrm{~m}$, trained as a trellis, and grown in a Malabon silty clay loam soil (fine, mixed, mesic Pachic Ultic Argixeroll) at the Lewis-Brown Experimental Farm in Corvallis, Ore. The plot was drip irrigated using two emitters per tree located at both sides of the trunk. Herbicides were used to maintain a vegetation-free strip within the row. Management practices were performed according to commercial practice. For the purpose of the experiment, 18 trees were selected randomly from a population of trees with uniform characteristics. Guard trees and rows separated all experimental trees, replicated six times. On 2 Oct. 1995, immediately after harvest, labeled B (99.63 atom \% ${ }^{10} \mathrm{~B}$ ) (Eagle Picher, Quapaw, Okla.) was applied as boric acid either to the soil or foliarly sprayed. The treatments were as follows: 1) foliar B at $375 \mathrm{mg} \cdot \mathrm{kg}^{-1}$, 2) foliar B at $375 \mathrm{mg} \cdot \mathrm{kg}^{-1}$ plus urea at $2.5 \%$ (wt/vol), and 3) soil $B$ application at the same per-tree rate as treatments 1 and 2 (16 g boric acid/tree).

For the soil application, the fertilizer was dissolved in 5 L of tap water and applied evenly under the tree canopy in the area wetted by the drip emitters. Foliar sprays were applied to the point of drip with a handgun sprayer. Before the foliar applications, the soil surface under the tree was covered with plastic to preclude direct addition of B into the soil. The treatment solution included a surfactant, $0.05 \%(\mathrm{v} / \mathrm{v})$ Triton X-100 (Sigma, St. Louis, Mo.) and had a final $\mathrm{pH}$ of 5.7. After several hours, when the solution on the plastic surface dried, the plastic under each tree was removed.

All tissues sampled (Table 1) were washed immediately in solutions of glassware detergent (Alconox; Alconox, Inc., White Plains, N.Y.), rinsed once in tap water, twice in distilled water, and then dried at $65^{\circ} \mathrm{C}$ for $5 \mathrm{~d}$. All tissues except buds and flowers were ground in a Wiley mill to pass a 40-mesh screen. Bud and flower tissues were ground with ceramic mortar and pestle. Ground samples were ashed in a muffle furnace at $500{ }^{\circ} \mathrm{C}$. Ash was dissolved in $5 \mathrm{~mL}$ of a $5 \% \mathrm{HNO}_{3}$ at room temperature, mixed, and allowed to settle. An aliquot was diluted (1:3) with double distilled water before analysis. To preclude contamination of $\mathrm{B}$, polyethylene scintillation vials were used to store the diluted samples. Total B and isotopic ratios $\left({ }^{10} \mathrm{~B} /{ }^{11} \mathrm{~B}\right.$ ion counts $\left./ \mathrm{s}\right)$ in the ashed extracts 
were determined using an inductively coupled plasma mass spectrometer (Elan 500; Perkin Elmer Corp., Norwalk, Conn.). A certified solution (National Institute of Standards and Technology) was used to calibrate the spectrometer. The following equation was used to determine the fraction of $\mathrm{B}$ derived from the fertilizer $(\mathrm{BFF})$ : BFF $=\left(\%{ }^{10} \mathrm{~B}_{t}-{ }^{10} \mathrm{~B}_{\mathrm{c}}\right) /(\%$ $\left.{ }^{10} \mathrm{~B}_{\mathrm{f}}-\%{ }^{10} \mathrm{~B}_{\mathrm{c}}\right) \times 100$. The subscripts $\mathrm{t}$, $\mathrm{c}$, and $\mathrm{f}$ refer to the atomic percentages of ${ }^{10} \mathrm{~B}$ in the tissue, the control (natural abundance), and the fertilizer, respectively.

Statistical analyses were performed using the GLM procedure of the SAS statistical package (SAS Institute, 1991). The data was analyzed as a completely randomized design. Duncan's multiple range test was used to separate treatment means found significantly different in the analysis of variance. Statistical significance was tested at the 5\% level.

\section{Results and Discussion}

Boric acid and urea concentrations (220 g and $2500 \mathrm{~g} / 100 \mathrm{~L}$, respectively) did not cause any leaf damage, and leaf fall occurred at the same time for treated trees and the rest of the trees in the plot.

Only small amounts of the soil-applied labeled $\mathrm{B}$ reached the aerial parts of the tree before leaf fall in comparison with the foliar application of B (Tables 2 and 3). About 2\% of the total B in the senescent leaves was soil derived, and during the winter, all aerial tissues sampled had, at most, $3 \%$ of B coming from the soil-applied fertilizer. Fall application of B to soil likely will not influence bud development or overcome transient B deficiency the following spring. Instead, roots retain most of the B absorbed, maintaining a high $\mathrm{B}$ concentration (Table 2) with about $60 \%$ of the root B being fertilizer derived (Table 3 ).

Boron has been considered an immobile nutrient under natural conditions (soil-derived B) (Mengel and Kirby, 1987; Raven, 1980). However, recent studies have shown that foliar-applied B is exported from treated leaves anywhere from a few hours (Picchioni et al., 1995) to a few days (Hanson et al., 1985; Hanson 1991b; Shu et al., 1993; Shu et al., 1994). In this study, the percent of B derived from foliar spray was higher for flower buds and flowers than for other organs (Table 3). This suggests that buds are a preferential sink for B mobilization after foliar applications. The concentration of total B in the tissues (Table 2) correlated well with their isotopic enrichment or the percentage of $\mathrm{B}$ derived from the fertilizer in the same tissues (Table 3). Flower buds had B concentration ranging from 39 $\mathrm{mg} \cdot \mathrm{kg}^{-1}$ in the soil application treatment to 62 $\mathrm{mg} \cdot \mathrm{kg}^{-1}$ in the foliar B treatment. All tissues had higher amounts of $\mathrm{B}$ derived from the foliar fertilizer when urea was added, but the

Table 1. Sampling dates and tissues used for isotopic B analysis of field-grown 'Delicious' apples.

\begin{tabular}{lll}
\hline Stage of growth & Date & Tissue \\
\hline Leaf fall & 7 Nov. & Senescent leaves $^{\mathrm{z}}$ \\
Dormant & $20 \mathrm{Dec}$. & Flower buds \\
Full bloom (FB) & $10 \mathrm{Apr}$-year-old shoot, scaffold bark, roots \\
After FB, $97 \mathrm{~d}$ & $17 \mathrm{July}$ & Flower clusters \\
\hline
\end{tabular}

${ }^{2}$ From current season's growth.

'Dissected flower buds.

Roots between 0.5 to $2 \mathrm{~cm}$ in diameter.

Table 2. Average B concentrations in $\mathrm{mg} \cdot \mathrm{kg}^{-1}$ in different tissues of 'Delicious' apple trees treated with $\mathrm{B}$ applied either to the soil or to the foliage immediately after harvest. Foliar applications were made with and without urea $(2.5 \% \mathrm{wt} / \mathrm{vol})$.

\begin{tabular}{lcccc}
\hline Sample & & \multicolumn{3}{c}{ Treatment } \\
\cline { 3 - 5 } date & Tissue & Soil B & Foliar B & Foliar B + urea \\
\hline 7 Nov. & Senescent leaves & $36.7 \mathrm{~b}^{\mathrm{z}}$ & $43.1 \mathrm{a}$ & $43.6 \mathrm{a}$ \\
20 Dec. & Flower buds & $39.1 \mathrm{~b}$ & $62.5 \mathrm{a}$ & $60.7 \mathrm{a}$ \\
& One-year-old shoot & $13.0 \mathrm{~b}$ & $18.4 \mathrm{a}$ & $17.5 \mathrm{a}$ \\
& Scaffold bark & $27.2 \mathrm{a}$ & $31.0 \mathrm{a}$ & $30.2 \mathrm{a}$ \\
& Roots & $43.0 \mathrm{a}$ & $16.3 \mathrm{~b}$ & $19.4 \mathrm{~b}$ \\
10 Apr. & Flower clusters & $32.1 \mathrm{c}$ & $40.9 \mathrm{~b}$ & $46.8 \mathrm{a}$ \\
17 July & Midshoot leaves & $29.0 \mathrm{~b}$ & $33.0 \mathrm{a}$ & $28.6 \mathrm{~b}$ \\
\hline
\end{tabular}

${ }^{2}$ Within each date and tissue, means with different letters are significantly different at $P=0.05$ using Duncan's multiple range test.

Table 3. Average percent of B derived from the labeled fertilizer in different tissues of 'Delicious' apple trees treated with B applied either to the soil or to the foliage immediately after harvest. Foliar applications were made with and without urea $(2.5 \% \mathrm{wt} / \mathrm{vol})$.

\begin{tabular}{lcccc}
\hline Sample & & \multicolumn{3}{c}{ Treatment } \\
\cline { 3 - 5 } date & Tissue & Soil B & Foliar B & Foliar B + urea \\
\hline 7 Nov. & Senescent leaves & $2.2 \mathrm{~b}^{2^{*}}$ & $12.6 \mathrm{a}$ & $14.5 \mathrm{a}$ \\
20 Dec. & Flower buds & $2.6 \mathrm{~b}$ & $35.5 \mathrm{a}$ & $42.1 \mathrm{a}$ \\
& One-year-old shoot & $3.0 \mathrm{~b}$ & $23.0 \mathrm{a}$ & $27.1 \mathrm{a}$ \\
& Scaffold bark & $1.3 \mathrm{~b}^{*}$ & $11.8 \mathrm{a}$ & $13.2 \mathrm{a}$ \\
& Roots & $59.6 \mathrm{a}$ & $6.2 \mathrm{c}$ & $12.5 \mathrm{~b}$ \\
10 Apr. & Flower clusters & $5.1 \mathrm{c}$ & $34.7 \mathrm{~b}$ & $48.7 \mathrm{a}$ \\
17 July & Midshoot leaves & $25.1 \mathrm{a}$ & $16.2 \mathrm{~b}$ & $19.3 \mathrm{~b}$ \\
\hline
\end{tabular}

${ }^{2}$ Within each date and tissue, means with different letters are significantly different at $P=0.05$ using Duncan's multiple range test.

*Not significantly different than 0 . addition of urea significantly increased the B derived from the foliar fertilizer only for the roots and flower clusters (Table 3 ). The results show that it is possible to mix both compounds in a postharvest fertilizer program if nitrogen is needed. Adding urea may enhance B uptake. However, since B alone substantially increases B concentrations in the flowers (Table 3), it may not be necessary to include urea in the mix if only B fertilization is desired.

Leaves are sensitive to high $\mathrm{B}$ concentration. Here, only $375 \mathrm{mg} \cdot \mathrm{L}^{-1} \mathrm{~B}(220 \mathrm{~g}$ boric acid $/ 100$ L) was enough to increase B concentration in the new growth the following spring (Table 2 ) in comparison with the soil application. If we are able to minimize B concentrations in the spray solution as we load storage tissues, it may be possible to include other nutrients in the postharvest foliar fertilizer mix for apples. Our work on pears was performed with 500 $\mathrm{mg} \cdot \mathrm{L}^{-1}$ of B without adverse effects (Sánchez et al., 1998).

The soil application had the highest percentage of B derived from the fertilizer for midshoot August leaves (Table 3). This may suggest that while root-stored B is not an important B source to flowers in early spring, it does become available to the leaves later in the season. It is also possible that some of the B applied in the previous fall was available once a canopy developed and soil uptake become important. In July, midshoot leaves had B concentrations from 29 to $33 \mathrm{mg} \cdot \mathrm{kg}^{-1}$ for the soil and foliar B treatments, respectively. Even though there is statistical difference between foliar B application and soil application, for practical orchard management purposes, the concentrations are the same - about $30 \mathrm{mg} \cdot \mathrm{kg}^{-1}$.

We conclude that B applied foliarly after harvest is translocated to above-ground storage organs before leaf fall and is then used the following season. In contrast, soil-applied B remained in roots during the winter and was less available to flower buds and flowers. The observations that fertilizer-derived B can be detected in some aerial tree parts in December, and in the flower clusters the following April, are important. The percentage of $\mathrm{B}$ derived from the labeled fertilizer was significantly different than zero for all but two tissues in the soil treatment: the senescent leaves in November and the scaffold bark in December. This indicates that some of the soil-applied B is absorbed and transported into the upper portions of the trees by December. Furthermore, detection of B in the roots of the foliarly-sprayed trees indicates a substantial basipetal movement of $\mathrm{B}$, which supports the conclusion that $\mathrm{B}$ is phloem mobile in apple (Brown and $\mathrm{Hu}, 1996$ ).

Although there is clear evidence that B is more mobile than previously thought, late-season foliar applications are still more effective at supplying B to flower buds and flower clusters than late-season soil applications.

Urea added to a foliar B application increased $\mathrm{B}$ concentration in the roots and flower clusters but to a lesser extent than has been observed in pears (Sánchez et al., 1998). A factor that may contribute to the species difference is differential timing of application; postharvest applications for pears usually are 
made substantially earlier than for apples.

Shoot leaves from all treatments collected midsummer had similar B concentrations even though treatments altered the amount of added $\mathrm{B}$ that was present in different tree tissues early in the season. Combining urea and $\mathrm{B}$ into a single postharvest foliar application is recommended when growers want to apply both $\mathrm{N}$ and $\mathrm{B}$.

\section{Literature Cited}

Argawala, S.C., P.N. Sharma, C. Chaterjee, and C.P. Sharma. 1981. Development and enzymatic changes during pollen development in boron deficient maize plants. J. Plant Nutr. 3:329-336.

Bajter, L.P. and A.H. Thompson. 1949. Effect of boric acid sprays during bloom upon the set of pear fruits. Proc. Amer. Soc. Hort. Sci. 53:141-142.

Beresford, R.M., I.J. Horner, and P.N. Wood. 2000. Autumn-applied urea and other compounds to suppress Venturia inaequalis ascospore production. Proc. 53rd N.Z. Plant Prot. Conf. 387-392.

Bramlage, W.J. and A.H. Thompson. 1962. The effects of early-season sprays of boron on fruit set, color, finish, and storage life of apples. Proc. Amer. Soc. Hort. Sci. 80:64-72.

Brown, P.H. 2001. Transient nutrient deficiencies and their impact on yield-A rationale for foliar fertilizers? Acta Hort. 564:217-223.

Brown, P.H. and H. Hu. 1996. Phloem mobility of boron is species dependent: Evidence for phloem mobility in sorbitol-rich species. Ann. Bot. 77:497-505.

Burchill, R.T. 1968. Field and laboratory studies of the effect of urea on ascospore production of Venturia inaequalis (Cke) Wint. Ann. Appl.
Biol. 62:297-307.

Callan, N.W., M.M. Thompson, M.H. Chaplin, R.L. Stebbins, and M.N. Westwood. 1978. Fruit set of italian prune following fall foliar and spring boron sprays. J. Amer. Soc. Hort. Sci. 103:252-257.

Chaplin, M.H., R.L. Stebbins, and M.N. Westwood. 1977. Effect of fall-applied boron sprays on fruit set and yield of italian prune. HortScience 12:500-501.

Dickinson, D.B. 1978. Influence of borate and pentaerythriol concentrations on germination and the tube growth of Lilium longiflurum pollen. J. Amer. Soc. Hort. Sci. 103:413-416.

Faust, M. 1989. Physiology of temperate zone fruit trees. Wiley, New York

Hanson, E.J. 1991a. Sour cherry trees respond to foliar boron applications. HortScience 26:1142-1145.

Hanson, E.J. 1991b. Movement of boron out of tree fruit leaves. HortScience 26:271-273.

Hanson, E.J. and P.J. Breen. 1985. Effects of fall boron sprays and environmental factors on fruit set and boron accumulation in italian prune flowers. J. Amer. Soc. Hort. Sci. 110:389-392.

Hanson, E.J., M.H. Chaplin, and P.J. Breen. 1985. Movement of foliar applied boron out of leaves and accumulation in flower buds and flower parts of italian prune. HortScience 20:747-748.

Kamali, A.R. and N.F. Childers. 1970. Growth and fruiting of peach in sand culture as affected by boron and fritted form of trace elements. J.Amer. Soc. Hort. Sci. 95:652-656.

Leece, D.R. 1976. Composition and ultrastructure of leaf cuticle from fruit trees, relative to differential absorption. Austral. J. Plant Physiol. $3: 833-847$.

Mengel, K. and E.A. Kirby. 1987. Principles of plant nutrition, p. 559-572. Intl. Potash Inst. Worblaufen-Bern, Switzerland.
Mills, H.A. and J.B. Jones. 1996. Plant analysis handbook II. MicroMacro Publ., Inc.

Peryea, F.J. 1994. Boron nutrition in deciduous tree fruit, p. 95-99. In: A.B. Peterson and R.G. Stevens (eds.). Tree fruit nutrition. Good Fruit Grower, Yakima, Wash.

Peryea, F.J., D. Nielsen, and G. Neilsen. 2003. Boron maintenance sprays for apple: Early-season applications and tank-mixing with calcium chloride. HortScience 38:542-546.

Picchioni, G.A., S.A. Weinbaum, and P.H. Brown. 1995. Retention and the kinetics of uptake and export of foliage-applied labeled boron by apple, pear, prune, and sweet cherry leaves. J. Amer. Soc. Hort. Sci. 120:28-35.

Raven, J.A. 1980. Short and long distance transport of boric acid in plants. New Phytol. 84:231-249.

Sánchez, E.E., H. Khemira, D. Sugar, and T.L. Righetti. 1995. Nitrogen management in orchards. In: P.E. Bacon (ed.). Nitrogen fertilization in the environment. Marcel Dekker, Inc., New York.

Sánchez, E.E., T.L. Righetti, and D. Sugar. 1998. Partitioning and recycling of fall applied boron in Comice pears. Acta Hort. 475:347-354.

SAS Institute, Inc. 1991. SAS/STAT user's guide, version 6. 4th ed. vols. 1 and 2. SAS Inst, Cary, N.C.

Shu, Z.H., G.H. Oberly, and E.E. Carry. 1993. The course study on the mobility pattern of distribution of foliar-applied boron in peaches. J. Plant Nutr. 16:1661-1673

Shu,Z.H., G.H.Oberly, and M. Rutzke. 1994. Absorption and translocation of boron to aerial tissues of fruiting Reliance peach trees. HortScience 29:25-27.

Vasil, I.K. 1963. Effect of boron on pollen germination and pollen tube growth. In: H.F. Linskens (ed.). Pollen physiology and fertilization. North Holland, Amsterdam. 